\title{
ANALISIS PENGGUNAAN MEDIA GRAFIS OLEH GURU MAPEL GEOGRAFI KELAS X SMAN 1
}

\author{
Utari Hadiningsih $^{1}$, Novita Sariani ${ }^{2}$ \\ Program Studi Pendidikan Geografi, Fakultas Ilmu Pendidikan dan Pengetahuan Sosial (IPPS) \\ IKIP-PGRI Pontianak ${ }^{1,2}$ \\ Email: novitasariani24@yahoo.co.id ${ }^{2}$
}

\begin{abstract}
Abstrak
Tujuan dari penelitian ini adalah untuk melihat bagaimana penggunaan media grafis oleh guru mata pelajaran geografi di kelas X SMA Negeri 1 Tanah Pinoh Kabupaten Melawi diterapkan dan untuk mengetahui serta memperoleh kejelasan, gambaran, tentang analisis penggunaan media grafis oleh guru mata pelajaran Geografi di Kelas X SMA Negeri 1 Tanah Pinoh Kabupaten Melawi. Penelitian ini menggunakan metode kualitatif dengan pendekatan deskriptif analitik, artinya peneliti akan melakukan analisis lebih dalam terkait dengan penggunaan media grafis dalam mata pelajaran geografi. Subjek dalam penelitian ini adalah siswa kelas X SMA Negeri 1 Tanah Pinoh Kabupaten Melawi Tahun Ajaran 2019. Hasil penelitian ini terlihat ketika menggunakan media grafis untuk pembelajaran geografi didapatkan peningkatan persentase menjadi 69,38\%, Sedangkan secara khusus dapat dirincikan melalui aspek-aspek penelitian yang dilakukan dalam penelitian, sebagai berikut: langkah-langkah penggunaan media grafis dapat dikategorikan "baik" dengan persentase 71,39\%., upaya pemanfaatan penggunaan media grafis dapat dikategorikan "baik" dengan persentase $71,76 \%$ dan kendala penggunaan media grafis dapat dikaterogikan "baik" dengan persentase 50,69\%.
\end{abstract}

Kata Kunci : Media Grafis, Guru, Pelajaran Geografi

\begin{abstract}
The purpose of this research is to see how the use of graphic media by geography subject teachers in class X SMA Negeri 1 Tanah Pinoh Melawi Regency is applied as well as to get the clarity, and the description about the analysis of the use of graphic media by Geography subject teachers in Class $X$ SMA Negeri 1 Tanah Pinoh, Melawi Regency. This study used a qualitative method with an analytic descriptive approach, that was, the researcher conducted a deeper analysis using graphic media in geography lessons. The subjects in this study were class X students of SMA Negeri 1 Tanah Pinoh, Melawi Regency in the academic year 2019. The results of this study were seen using graphic media for learning geography to increase the proportion to $69.38 \%$, while specifically it could be detailed through the research aspects carried out in research, as follows: the steps for using graphic media can be categorized as "Good" with a percentage of $71.39 \%$, the efforts to use graphic media can be categorized as "Good" with a percentage of $71.76 \%$, and the constraints on the use of graphic media can be categorized as "good" with a percentage of $50.69 \%$
\end{abstract}

Key Words : Graphic Media, Teacher, Geography Lessons

\section{PENDAHULUAN}

Pendidikan merupakan salah satu faktor utama dalam rangka meningkatkan sumber daya manusia, karena dengan pendidikan yang tepat serta memadai seseorang mampu memberdayakan diri dan menggali potensi dirinya untuk mencapai kesejahteraan di masa depan dengan mengenyam pendidikan seseorang akan memperoleh ilmu pengetahuan yang bermanfaat untuk mencerna, merencanakan dan menganalisa apa yang sebaiknya dilakukan, dengan kata lain pendidikan ilmu pengetahuan adalah aset seseorang untuk tumbuh dan berkembang dalam hidup bermasyarakat. Dalam pelaksanaannya, guru dituntut untuk memiliki berbagai keterampilan atau kreativitas mengajar, strategi belajar mengajar yang tepat dan kemampuan melaksanakan evaluasi yang baik dengan wawasan yang luas diharapkan guru mampu memperhitungkan berbagai kemungkinan yang akan terjadi dengan 
mempertimbangkan kondisi sekarang dan pengalaman masa lalu. Sejalan dengan hasil penelitian yang mengemukakan bahwa guru merupakan komponen yang sangat penting, yang menentukan dalam proses pendidikan secara keseluruhan yang harus dapat diperhatikan sentral pertama dan utama [1].

Kemampuan guru merencanakan kegiatan pembelajaran dengan penggunaan media grafis pada mata pelajaran geografi merupakan hal yang sangat menarik, positif, dan inovatif. Dengan penggunaan media grafis dapat menimbulkan minat belajar siswa, karena siswa dapat melihat langsung serta bisa menyesuaikan dengan mata pelajaran geografi itu sendiri, sehingga perasaan yang bosan dan jenuh dapat berubah menjadi sikap ingin tahu yang besar. Selain itu, sejalan dengan hasil penelitian media grafis merupakan media visual yang berfungsi untuk menyalurkan pesan dari sumber ke penerima pesan melalui perpaduan antara pengungkapan kata-kata dan gambar [2].

Media bukan hanya berupa alat atau bahan saja, tetapi media pembelajaran meliputi segala sesuatu yang dapat menyalurkan pesan, dapat merangsang pikiran, perasaan dan kemauan siswa, sehinga dapat mendorong terciptanya proses belajar pada diri siswa [3]. Proses kegiatan pembelajaran ini menjadikan siswa dapat berpikir kratif dalam melakukan kegiatan pembelajaran, sehingga pembelajaran yang dilakukan menjadi lebih bermakna dengan mengunakan media yang tepat.

Media grafis sering juga disebut media dua dimensi yaitu media yang mempunyai ukuran panjang dan lebar [4]. Media grafis dapat didefinisikan sebagai media yang mengkombinasikan fakta dan gagasan secara jelas, kuat dan terpadu melalui kombinasi pengungkapan kata-kata melalui gambar [5]. Alasan peneliti menggunakan media grafis sebagai media dalam pembelajaran geografi dimana dalam pembelajaran geografi digunakan peta dan globe, maka dengan adanya media grafis ini dapat memberikan kemudahan guru dalam menyajikan pembelajaran di kelas dan juga dapat memudahkan siswa untuk dapat lebih memahami karena disajikan dalam bentuk visual, gambar dan juga warna yang manarik namun memiliki arti dan makna tersendiri.

Berdasarkan uraian di atas, maka untuk meningkatkan pemahaman siswa perlu adanya media pembelajaran yang tepat. Media grafis menjadi salah satu media yang efektif digunakan dalam kegiatan pembelajaran di kelas. Peneliti juga ingin menanalisa terkait bagaimana media grafis digunakan dalam proses pembelajaran mulai dari langkah-langkah guru dalam meberikan pembelajaran, bagaimana upaya guru dalam memanfaatkan media grafis dalam pembelajarn dan juga apa saja kendala yang ditemui oleh guru ketika melakukan pembelajaran dengan menggunakan media grafis.

\section{METODE}

Metode pada dasarnya adalah cara-cara yang digunakan untuk mencapai suatu tujuan. Jadi metode penelitian pada dasarnya merupakan cara ilmiah untuk mendapatkan data dengan tujuan dan kegunaan tertentu. Jadi dapat disimpulkan bahwa metode penelitian merupakan cara ilmiah untuk mendapatkan data yang valid dengan tujuan dapat ditemukan, dikembangkan, dan dibuktikan, suatu pengetahuan tertentu sehingga pada gilirannya dapat digunakan untuk memahami, memecahkan dan mengantisipasi masalah dalam bidang pendidikan [6].

Penelitian ini menggunakan data dan sumber data berupa data primer dan data sekunder, setelah semua terkumpulkan dan 
memenuhi syarat, selanjutnya dianalisis dengan menggunakan teknik analis data, sebagai berikut: pengumpul data, reduksi data, penyajian data dan kesimpulan. Penelitian ini jumlah subjek penelitian berjumlah 36 siswa yang terdiri dari lakilaki berjumlah 15 orang dan perempuan berjumlah 21 orang di kelas X SMA Negeri 1 Tanah Pinoh Kabupaten Melawi. Lokasi penelitian ini adalah SMA Negeri 1 Tanah Pinoh Kabupaten Melawi. Secara administratif berada di Jln. Pengeran Agung Kertasari No.155 kecamatan Tanah Pinoh, Kabupaten Melawi Provinsi Kalimatan Barat. Penelitian ini menggunakan teknik pengumpulan data seperti observasi langsung, komunikasi tidak langsung, komunikasi langsung dan dokumentasi. Alat pengumpulan data yang digunakan dalam penelitian ini, seperti panduan observasi, angket, panduan wawancara dan dokumentasi. Dalam penelitian ini juga menguji keabsahan data dengan menggunakan Teknik triangulasi dan alat yang digunakan yaitu pengumpul data, dapat dilihat pada gambar di bawah ini:

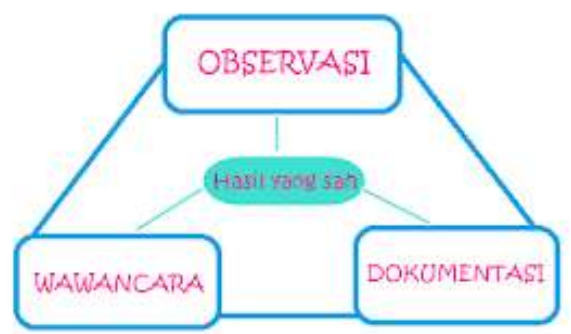

\section{Gambar 1. Teknik Triangulasi} Penelitian

\section{HASIL DAN PEMBAHASAN}

Langkah-Langkah Penggunaan Media Grafis oleh Guru Mata Pelajaran Geografi di Kelas X SMA Negeri 1 Tanah Pinoh Kabupaten Melawi Tahun 2019.

Berdasarkan hasil penelitian dapat dideskripsikan bahwa guru menggunakan media grafis pada mata pelajaran geografi, guru mempersiapkan media grafis dengan rapi dan menyesuaikan media grafis dengan materi yang akan disampaikan. Beberapa aspek dalam penggunaan media grafis oleh guru mata pelajaran geografi, meliputi: a) Persiapan penggunaan media grafis, b) Pelaksanaan penggunaan media grafis, c) Evaluasi.

Adapun langkah-langkah penggunaan media grafis oleh guru mata pelajaran geografi meliputi:

1) Mengetahui materi apa yang akan diajarkan. Sebelum kita menyiapkan media grafis yang akan kita tampilkan kepada siswa terlebih dahulu kita harus mengetahui materi yang akan kita sampaikan kepada siswa. Sehingga materi dan media grafis memiliki keterkaitan dalam penyampaian materi.

2) Menyediakan gambar dan foto sesuai dengan materi. Setelah kita mengetahui materi yang akan kita sampaikan kepada siswa, maka tahap selanjutnya kita mencari gambar dan foto sesuai dengan materi yang akan diajarkan serta melengkapi kebutuhan lainnya, seperti: menyediakan lem kertas, tali, dan gabus yang digunakan guru hanya berukuran $\mathrm{P}=59 \mathrm{~cm}$ dan $\mathrm{L}=39 \mathrm{~cm}$.

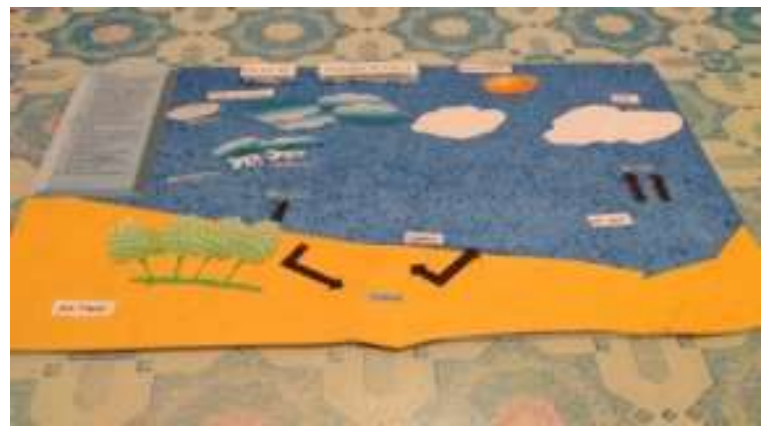

\section{Gambar 2. Media Grafis}

3) Merancang media grafis yang akan di gunakan. Setelah semua keperluan dalam pembuatan media grafis sudah tersedia, tahap selanjutnya kita 
merancang atau membuat konsep dalam pembuatan media grafis tersebut. Setelah media grafis selesai, maka media grafis tersebut dihiasi sesuai keinginan, sehingga siswa tertarik dalam menerima materi yang disampaikan.

Berdasarkan hasil penelitian yang saya lakukan di SMA Negeri 1 Tanah Pinoh Kabupaten Melawi dapat disimpulkan bahwa langkah-langkah penggunaan media grafis oleh guru mata pelajaran geografi di kelas X SMA Negeri 1 Tanah Pinoh Kabupaten Melawi tahun 2019, telah terlaksana serta dapat dikategorikan"Baik" dengan memperoleh persentase sebesar $71.39 \%$.

\section{Upaya Pemanfaatan Penggunaan Media Grafis oleh Guru Mata Pelajaran Geografi di Kelas X SMA Negeri 1 Tanah Pinoh Kabupaten Melawi Tahun 2019.}

Berdasarkan hasil penelitian di SMA Negeri 1 Tanah Pinoh Kabupaten Melawi, dapat dideskripsikan bahwa penggunaan media grafis yang baik harus menyesuaikan media grafis dengan materi serta membuat media grafis yang unik, sehingga siswa tertarik dalam proses kegiatan belajar mengajar dalam kelas. Tetapi kekurangan pemahaman guru dalam membuat media grafis membuat penggunaan media grafis menjadi terhambat, karena kesusahan dalam menyesuaikan media grafis dengan materi yang akan disampaikan. Kendala penggunaan media grafis oleh guru mata pelajaran geografi dapat diupaya pemanfaatan penggunaan media grafis yaitu:

1) Mengadakan pelatihan atau seminar penggunaan media grafis. Berdasarkan hasil wawancara mendalam dengan Kepala Sekolah dapat dideskripsikan bahwa dalam penggunaan media grafis untuk meningkatkan pemahaman guru dalam menyesuaikan media grafis dengan materi, jika anggaran dari pihak sekolah sudah mencukupi, sekolah akan mengadakan suatu pelatihan atau seminar untuk semua guru di SMA Negeri 1 Tanah Pinoh Kabupaten Melawi tentang penggunaan media grafis oleh guru dalam proses belajar mengajar. Peserta yang ikut dalam pelatihan atau seminar tentang penggunaan media grafis dalam proses kegiatan belajar mengajar khusus seluruh guru SMA Negeri 1 Tanah Pinoh Kabupaten Melawi. Pelatihan atau seminar ini bertujuan untuk menambahkan pengetahuan guru serta dapat menigkatkan sistem belajar mengajar guru di dalam kelas, sehingga siswa tidak bosan dalam menerima materi yang disampaikan.

2) Manfaatkan fasilitas dari sekolah. Berdasarkan hasil penelitian dapat dideskripsikan bahwa dalam proses kegiatan belajar mengajar mengalami kendala penggunaan media grafis oleh guru mata pelajaran geografi dapat diupayakan pemanfaatan dengan menggunakan media grafis yang sudah disediakan, jika materi yang akan disampaikan sesuai dengan media yang disediakan oleh pihak sekolah seperti: peta, globe, atlas dan alat pendukung lainnya. Selain itu, guru juga bisa memanfaatkan proyektor dalam penyampaikan materi, sehingga guru dipermudahkan dalam penggunaan media grafis.

3) Penambah kecepatan mega bits per second (MBPS). Perkembangan teknologi informasi saat ini telah menjalar dan memasuki setiap aspekaspek kehidupan. Teknologi informasi saat ini memainkan peranan yang besar didalam pendidikan, karena dengan internet guru dapat mencari informasi tentang penyampaian materi yang bervariasi. Sehingga siswa tidak bosan dan jenuh saat mendengarkan guru 
menyampaikan materi. Karena jaringan informasi (internet) di SMA Negeri 1 Tanah Pinoh Kabupaten Melawi masih keterbatasan pemakaian sehingga guru kesusahan dalam mencari informasi dalam penggunaan media grafis yang bervariasi. Jadi kebijakan dari pihak sekolah akan menambahkan kecepatan mega bits per second (MBPS).

4) Menggunakan alam sekitar sebagai objek pembelajaran. Media pembelajaran merupakan alat bantu yang mempermudahkan seorang guru dalam menyampaikan materi, dengan menggunakan media pembelajaran yang dilaksanakan dapat terlaksana secara efektif. Berbicara mengenai pembelajaran geografi memang baiknya seorang siswa tidak hanya diberikan berupa materi-materi ceramah ataupun sekedar menghafal saja, hal ini sangat menjenuhkan bagi siswa. Karena pelajaran geografi merupakan pembelajaran yang sangat menarik untuk dipahami ketika siswa mulai memahami maka terbangunlah rasa ingin tahunya, apalagi siswa dibawa langsung alam sekitar pasti tumbuhlah rasa kecintaan siswa dalam menjaga kelestarian lingkungan sekitar.

5) Memperdalam penggunaan media grafis. Penggunaan media grafis sangat membantu untuk proses kegiatan belajar mengajar serta memudahkan guru dalam menyampaikan materi. Maka dari itu, guru ingin memperdalam atau mempelajari penggunaan media grafis dengan cara mencari informasi lebih luas, sehingga penggunaan media grafis tidak hanya tempelan gambar dan foto di gabus saja, tetapi guru juga akan menampilkan media grafis lebih bervariasi.

Berdasarkan hasil penelitian di SMA Negeri 1 Tanah Pinoh Kabupaten Melawi tahun 2019 dapat disimpulkan bahwa upaya pemanfaatan penggunaan media grafis oleh guru mata pelajaran geografi dapat dikategorikan "Baik" dengan memperoleh persentase sebesar $71,76 \%$. Pihak sekolah akan melakukan kegiatan pelatihan atau seminar tentang penggunaan media grafis dalam proses kegiatan belajar mengajar khusus seluruh guru di SMA Negeri 1 Tanah Pinoh Kabupaten Melawi.

\section{Kendala Penggunaan Media Grafis Oleh Guru Mata Pelajaran Geografi di Kelas $X$ SMA Negeri 1 Tanah Pinoh Kabupaten Melawi Tahun 2019.}

Berdasarkan hasil penelitian di SMA Negeri 1 Tanah Pinoh Kabupaten Melawi dapat dideskripsikan bahwa dalam persiapan dan pelaksanaan penggunaan media grafis sudah bejalan dengan baik, tetapi di setiap persiapan maupun pelaksanaan penggunaan media grafis adakalanya mengalami kendala atau permasalahan penggunaan media grafis, dari hasil penelitian kendala penggunaan media grafis meliputi:

Tabel 1. Temuan Kendala Penggunaan Media Grafis

\begin{tabular}{lll}
\hline No & Aspek Kendala & Keterangan \\
\hline 1 & $\begin{array}{l}\text { Kesesusahan dalam } \\
\text { menyesuaikan media } \\
\text { grafis dengan materi }\end{array}$ & Guru \\
2 & $\begin{array}{l}\text { Kekurangan bahan dan } \\
\text { alat }\end{array}$ & Guru \\
3 & $\begin{array}{l}\text { Keterbatasan jaringan } \\
\text { informasi (internet) }\end{array}$ & Guru \\
4 & $\begin{array}{l}\text { Keterbatasan anggaran } \\
\text { dari pihak sekolah } \\
\text { Kekurangan fasilitas } \\
\text { dari pihak sekolah }\end{array}$ & Kepala sekolah \\
\multicolumn{2}{c}{ Sumber: Hasil Wawancara, Tahun 2019 }
\end{tabular}

Berdasarkan dari hasil penelitian yang saya lakukan di SMA Negeri 1 Tanah Pinoh Kabupaten Melawi dapat disimpulkan bahwa kendala penggunaan media grafis oleh guru mata pelajaran geografi di kelas X SMA Negeri 1 Tanah Pinoh Kabupaten Melawi tahun 2019, dapat dikategorikan "Baik" dengan memperoleh persentase 
$50,69 \%$, sehingga penggunaan media grafis oleh guru mata pelajaran geografi tidak bervariasi atau dalam pembuatan media grafis tidak maksimal.

Media grafis seperti gambar, foto, grafik, bagan atau diagram, poster kartun, komik dan lain-lain. Media grafis sering juga disebut media dua dimensi, yakni media yang mempunyai ukuran panjang dan lebar [7]. Penggunaan gambar haruslah disesuaikan dengan tingkatan, kondisi, dan situasi anak sehingga pembelajaran dengan menggunakan media gambar bisa efektif. Hal tersebut akan menambah kreativitas siswa dan memperkaya pengalaman serta memperbaiki kekurangjelasan, yang pada akhirnya tujuan pembelajaran bisa tercapai dengan baik [8]. Pada penelitian yang telah dilakukan terlihat bagaimana langkahlangkah guru dalam melakukan pembelajaran dengan media grafis, bagaimana guru memanfaatkannya dan kendala apa saja yang ditemui ketika melakukan pembelajaran dengan menggunakan media grafis.

Dengan menggunakan media grafis maka siswa akan menjadi lebih senang dalam proses pembelajaran karena berisi gambar -gambar yang menarik, sehingga siswa menjadi lebih bersemangat dalam mengikuti proses pembelajaran dan berpengaruh terhadap hasil belajar siswa [9]. Penggunaan media grafis menjadikan proses pembelajaran berjalan denganefektif dan menarik [10]. Faktor pengalaman yang dimiliki oleh guru tersebut sehingga untuk memulai pembelajaran guru dapat memilih media yang tepat untuk yang sesuai dengan materi pembelajaran [11]. Peningkatan kemampuan dan pemahaman siswa terhadap materi yang disajikan oleh guru terlihat ketika antusisme siswa dalam mengikuti pembelajaran dengan menggunakan media grafis. Kejadian ini menjadi bukti bahwa bagaimana peran media yang tepat digunakan dalam proses pembelajaran guru menjadi faktor penting tercapainya komptensi siswa, sehingga pembelajaran menjadi lebih bermakna.

\section{SIMPULAN}

Berdasarkan hasil dan pembahasan yang telah disajikan di atas, maka dapat disimpulkan penggunaan media pembelajaran yang tepat dapat mendukung kegiatan pembelajaran yang efektif dan efisien. Media grafis terbukti telah memberikan kemudahan bagi guru dalam melakukan kegiatan pembelajaran yang bermakna, faktor lainnya adalah pengalaman guru dalam menggunakan media pembelajatan yang tepat untuk setiap materi yang disampaikan.

\section{DAFTAR PUSTAKA}

[1] Suyanto dan Ji. Asep. Menjadi Guru Profesional. Jakarta: Erlangga, 2013.

[2] Rusby, Zulkifli, dkk. "Upaya Guru Mengembangkan Media Visual dalam Proses Pembelajaran". J. Al Hikmah, vol. 14, no. 1, pp. 18-37, 2017.

[3] S. W. Setianingsih, E. Banowati, dan B. Santoso. "Ketepatan Pemilihan dan Penggunaan Media Pembelajaran Geografi SMA Negeri di Kabupaten Jepara". Edu Geogr., vol. 1, no. 2, pp. 57-62, 2013.

[4] S. Hayati, A. Yani, dan B. Waluya. "Penggunaan Media Komik Tanpa Kata untuk Meningkatkan Keberanian Mengemukakan Pendapat pada Mata Pelajaran Geografi di SMPN 12 Bandung". $J$. Geogr. Gea, vol. 6, no. 2, pp. 1-18, 2016, doi: 10.17509/gea.v6i2.1740.

[5] A. Purwani, L. Fridani, dan F. Fahrurrozi. "Pengembangan Media Grafis untuk Meningkatkan Siaga Bencana Banjir". J. Obs. J. Pendidik. Anak Usia Dini, vol. 3, no. 1, pp. 55-67, 2019, doi: 10.31004/obsesi.v3i1.142.

[6] Sugiyono. Memahami Penelitian 
Kualitatif. Bandung: Alfabeta, 2016.

[7] I. R. Karo-karo dan R. Rohani. "Manfaat Media dalam Pembelajaran". Axiom, vol. 7, no. 1, pp. 91-96, 2018.

[8] N. M. C. K. Dewi, I. N. Sudiana, dan G. Artawan. "Penerapan Model Pembelajaran melalui Pengalaman Berbantuan Media Grafis untuk Meningkatkan Kemampuan Menulis Puisi Siswa Kelas VIII A SMP Dharma Wiweka Denpasar". $J$. Pendidik. Bhs. dan Sastra Indones. Undiksha, vol. 2, no. 1, pp. 1-11, 2014.

[9] N. L. M. P. Dewi, I. G. A. A. S. Asri, dan I. K. N. Wiyasa. "Model
Pembelajaran Take and Give Berbantuan Media Grafis terhadap Hasil Belajar PKN SD". Mimb. PGSD Univ. Pendidik. Ganesha, vol. 2, no. 1, p. 2014, 2014.

[10] M. F. Siburian. "Efektivitas Penggunaan Media Grafis untuk Meningkatkan Hasil Belajar IPA". Form. J. Ilm. Pendidik. MIPA, vol. 6, no. 2, pp. 125-133, 2016, doi: 10.30998/formatif.v6i2.946.

[11] L. P. Sawiji dan S. Parman. "Kendala Guru IPS dalam Penggunaan Media Peta dan Globe pada Pembelajaran Geografi”. Edu Geogr., vol. 3, no. 3, pp. 31-36, 2015. 